\title{
Von Hayek and Ordoliberalism on Justice
}

\section{Manuel Wörsdörfer ${ }^{1}$}

Forthcoming in: Journal of the History of Economic Thought Vol. 35(3); pp. 291-317.

\section{Introductory Remarks: State of Research}

Many scholars and scientists have dealt with Ordoliberalism and von Hayek at great length and compared in particular the socio-economic theories of Walter Eucken and Friedrich August von Hayek. ${ }^{2}$ To name just a few: Watrin (2000) analyzes the varying concepts of the state and government tasks. According to him, Eucken as a member of the Freiburg School of Law and Economics is favouring - more or less - a deliberately designed and 'made' (constructivist) order while von Hayek on the other hand is highly in favour of an evolutionary, 'grown' (spontaneous) order (i.e. constructivist rationalism vs. evolutionary/critical rationalism; see Hayek 1973). Streit and Wohlgemuth (2000a and 2000b) in turn point at the diverging leitmotifs underlying the conceptions of von Hayek and Eucken: In the centre of Ordoliberalism is the topic of private power or - to put it differently - the question of how to avoid, eliminate or at least reduce the concentration of power in the economic and political sphere. To the contrary, von Hayek is not so much concerned with the problem of power as with the epistemological topic of knowledge. To be more precise: His major concern is the division or fragmentation of widely dispersed knowledge which can be utilized via competitive market processes operating as a discovery procedure. A similar approach as in Streit and Wohlgemuth (2000a and 2000b) and Watrin (2000) is presented by Kolev (2008). Kolev not only discusses the distinct roles of the state; additionally, he analyses Eucken's and von Hayek's concepts of monetary, competition and social policy as well. According to Pies (2001: pp. 123), the differences between Eucken and von Hayek are in fact

\footnotetext{
${ }^{1}$ Address for correspondence: Manuel Wörsdörfer, Postdoctoral Research Fellow of the Cluster of Excellence 'The Formation of Normative Orders'; Postal address: Goethe University Frankfurt, Grueneburgplatz 1, 60323 Frankfurt am Main/Germany; Phone: +49 (0)69-798-34782; Fax: +49 (0)69-798-35015; E-mail: woersdoerfer@wiwi.uni-frankfurt.de.

This paper was presented at the conference 'Justice and Economics: Ancient Doctrines and Modern Theories' at the University of Toulouse/France (16-17 June 2011). The author would like to thank the participants of the session 'Justice sociale et libéralisme' and three anonymous reviewers for their constructive comments. They helped to improve the paper significantly.

2 The biographical and personal relationship-level (between von Hayek and Eucken) is presented in Karabelas 2010: pp. 69; a distant and critical review of neo-/Ordoliberalism may be found in Wörsdörfer 2011a (see especially the chapter 'Beyond Ordoliberalism?').
} 
merely of minor importance. The only true difference is that Eucken presents a theory of power while von Hayek presents a theory of knowledge. Finally, Bönker and Wagener (2001) are again emphasizing the differences between a self-generating, spontaneous formation of order and a political artefact-order. Besides the role of the state and the agenda of economic policy, they are referring to philosophy of science-aspects resulting from the diverging underlying leitmotifs already mentioned in the two essays by Streit and Wohlgemuth.

In retrospect, it is striking that most of the just mentioned subsequent interpretations are highlighting the parallels while the differences are either of minor importance, as in the work of Pies, or they are presented one-sidedly: Von Hayek is often regarded as an Ordoliberal and the Freiburg School of Law and Economics, Ordoliberalism in the wider sense, and von Hayek are often talked about in the same breath (cp. Kolev 2010). The major differences are traced back to the diverging leitmotifs (power vs. knowledge) and/or the two concepts of order: made or grown order or in the Hayekian terminology: taxis and kosmos. These disparities are, no doubt, of eminent significance and they must not be underestimated and neglected. However, and that is essential to note, considerable differences can be found on different topics and not only on the just mentioned ones.

Variations and disparities between von Hayek and Ordoliberalism in the wider sense can in fact be detected on diverse levels ${ }^{3}:$ 1. philosophy of science: von Hayek's recognition of incomplete information, limits of reason and bounded rationality and his warning against pretence of knowledge vs. the ordoliberal quest for absolute truth and inherent epistemic optimism and malleability due to pure human reason; 2. setting dissimilar priorities: von Hayek's focus on the problem of knowledge and his re-interpretation of competition as a discovery procedure vs. the ordoliberal focus on the problem of power and its reinterpretation of competition as an instrument of disempowerment; ${ }^{4}$ 3. social philosophy: von Hayek's focus on regulatory ethics vs. the ordoliberal combination of regulatory and individual/virtue ethics pegged to the topics of Gesellschaftskrisis (societal crisis of the present) and Vital Policy as one major peculiarity of German Ordoliberalism; 4. genesis of norms: von Hayek's cultural-evolutionary vs. the ordoliberal constructivist-elitist approach ${ }^{5}$;

\footnotetext{
3 The first two dimensions are mainly based on the literature mentioned prior. The third, fourth and fifth dimensions can be found in the work of Wörsdörfer 2010; 2011a and 2011b.

${ }^{4}$ In this regard von Hayek's laissez faire attitude towards (private and natural) monopolies and large size corporations is remarkable (cp. Hayek 1979: pp. 77; Hennecke 2008: pp. 150). He even speaks of a 'problem of antimonopoly legislation' due to the discretionary and arbitrary powers of public authorities intervening in market processes. His mistrust in state authorities is even higher than his mistrust in monopolies and big enterprises. ".. it is not monopoly as such but only the prevention of competition which is harmful. [...] a monopoly that rests entirely on superior performance is wholly praiseworthy ..." (both: Hayek 1979: p. 83).

${ }^{5} \mathrm{Cp}$. for a criticism of the Freiburg School in terms of its 'crypto-normative' (i.e., elitist-expertocratic) argument (including a lack of democratic legitimacy): Kirchgässner 1988; Vanberg 1988 and Feld/Köhler 2011. For a
} 
and 5. notion of freedom: von Hayek's negative concept of liberty vs. the ordoliberal combination of negative and positive (Kantian) liberty.

As a consequence it should be possible to make an important distinction within neoliberalism itself which contains at least two factions: von Hayek's evolutionary liberalism and German Ordoliberalism. The current paper builds on the work of Renner (1999/2000), Quaas (2000), Hennecke (2008) and others evaluating the different varieties inside neoliberalism.

Coming back once again to the literature review on the current state of research, what becomes clear and obvious is the fact that the theories of justice are more or less neglected. Only a few paragraphs are dedicated to this topic (cp. Bönker/Wagener 2001: pp. 190-191; Streit/Wohlgemuth 2000a: pp. 486-489 and Streit/Wohlgemuth 2000b: pp. 249-251). The only exception in this regard is Kolev. The following essay not only takes the neoliberal separation of different varieties stated by Renner et al. as granted; it proceeds further: it focuses on the topic of justice and elaborates the (slightly) differing conceptions of justice within neoliberalism. Thus, the specific contribution of the paper is that it fills the gap and that it adds a further, a sixth dimension of differences (which is highly interconnected with the already mentioned differing conceptions of genesis of norms). To put it differently: In the current paper I try to analyze the (often neglected) subtle differences between von Hayek, Eucken, Röpke and Rüstow with special emphasis on their theories of justice and I will approach von Hayek's evolutionary liberalism and German Ordoliberalism from a theoreticalhistorical and economic-ethical justice perspective. As stated above, I will not only focus on Eucken and von Hayek; instead, I will include the concepts of justice developed by Rüstow and Röpke as well and in consequence, broaden the perspective incorporating Eucken as a member of the Freiburg School of Law and Economics and Rüstow and Röpke as representatives of Ordoliberalism in the wider sense.

The paper tackles these topics in three steps: After having briefly re-examined and discussed the existing literature and provided the reader with a literature overview on the decade-long debate on von Hayek and Ordoliberalism in the introductory chapter, part two describes von Hayek's conception of commutative justice respectively justice of rules and procedures (rather than end-state justice). The third part examines Eucken's, Rüstow's and Röpke's theories of justice which consists of a mixture of commutative and distributive justice. In the fourth paragraph I draw a comparison between the ideas of justice developed by Eucken,

critical review of Ordoliberalism and comparison between von Hayek and Ordoliberalism with regard to the different genesis of norms see also Wörsdörfer 2010 and 2011a. 
Röpke, and Rüstow on the one hand and von Hayek on the other. The essay ends with a summary of my main findings.

\title{
2. Social Justice as a 'Weasel-Word'? Von Hayek on Justice
}

\begin{abstract}
"It is now necessary clearly to distinguish between two wholly different problems which the demand for 'social justice' raises in a market order. The first is whether within an economic order based on the market the concept of 'social justice' has any meaning or content whatever. The second is whether it is possible to preserve a market order while imposing upon it (in the name of 'social justice' or any other pretext) some pattern of remuneration based on the assessment of the performance or the needs of different individuals or groups by an authority possessing the power to enforce it. The answer to each of these questions is a clear no" (Hayek 1976: pp. 67).

“... the addition of the adjective 'social' makes them capable of meaning almost anything one likes. The word has indeed become one of the chief sources of confusion of political discourse and can probably no longer be reclaimed for a useful purpose" (Hayek 1976: pp. 79).
\end{abstract}

Von Hayek's trilogy Law Legislation and Liberty is often considered as his opus magnum; the second volume is entitled The Mirage of Social Justice - so this trilogy is of particular importance in the field of justice and deserves a detailed analysis.

What becomes clear right from the start is the interconnectedness of von Hayek's theory of impersonal justice based on formal (abstract and end-independent) rules ${ }^{6}$ with the twinconcepts of cultural evolution and spontaneous order. At the centre of his negative theory of justice (Hayek 1979: pp. 130) are the legal rules of just conduct and the constitutional 'design' of political institutions (Hayek 1976: p. 100). It is not a positive conception of justice which makes it an obligation of administration and government to distribute and reallocate wealth equally among citizens (p. 103). Rather, what is important is to evade injustice and, thus, approach the (unattainable) ideal state of absence of injustice (p. 54). As claimed by von Hayek, a positive (i.e. agreeable and consensual) criterion of justice does simply not exist (p. $42),{ }^{7}$ only negative ones are obtainable indicating what is unjust. Merely an objective and that means an interpersonally valid (negative) test of injustice enables us gradually to remove these kinds of rules which prove to be unjust and which are, therefore, not universalizable. ${ }^{8}$

\footnotetext{
${ }^{6}$ Since von Hayek uses different attributes to describe these general rules (i.e., formal, negative, abstract, endindependent, etc.), I will use similar, synonymous attributes as well throughout the text.

7 I.e. complete lack of a recognized standard of 'social justice (cp. Hayek 1976: pp. 90).

${ }^{8}$ Cp. Hayek 1976: p. 43.
} 
Instead of granting (non-achievable and non-enforceable) positive rights, the socio-political order should rest on negative rights and commutative justice. Such an ideal of impersonal justice (rather than sectional justice) is based on formal rules, and to be more precise, it is based on spontaneously grown rules, not on deliberately planned/made rules brought about by deliberate human design (i.e. "the result of human action but not of human design" (Hayek (following Ferguson) 1973: p. 20)). This evolutionary approach to law involves the rejection of the interpretation of law as a deliberate construct of super-natural forces (Hayek 1976: p. 60). According to von Hayek, it is rather improbable in a Great Society to agree on ends. Agreement is more likely to be reached on means or to put it differently on rules of just conduct $^{9}$ : “... rules of just conduct serve not (concrete or particular) ends but (abstract and generic) values ...” (p. 14). These rules intend to apply for an indefinite period, “... to an unknown number of future instances and to the acts of an unknown number of persons, and merely states certain attributes which any such action ought to possess ...” (p. 14; see also p. 35 and 130). These abstract rules embody the knowledge and traditional experience which has been generated and transmitted over time. Thus, they are a device, a tool for coping with human ignorance and uncertainty. Abstract rules are the guides in a world in which most things are unknown (i.e. limits of reason and lack of knowledge ${ }^{10}$; see pp. 8). The big advantage of such rules - together with other impersonal and abstract mechanisms like competitive markets - is the utilization of factual knowledge widely dispersed among thousands of individuals (i.e. fragmentation of knowledge (Hayek 1973: p. 14; 1976: p. 8)). The task of public authorities is the enforcement of the observance of abstract rules of (just) conduct, the preservation of a rule-governed spontaneous order (end-independent and purpose-free kosmos instead of taxis/organization with its end-governed character): "Only if applied universally, without regard to particular effects, will they serve the permanent preservation of the abstract order, a timeless purpose which will continue to assist the individuals in the pursuit of their contemporary and still unknown aims. Those rules which are common values serve the maintenance of an order of whose existence those who apply them are often not even aware" (p. 17). The key feature of such negative rules restraining

\footnotetext{
${ }^{9}$ Cp. Hayek 1976: p. 3.

${ }^{10}$ Cp. Hayek 1976: p. 39.: "It is as much because we lack the knowledge of a common hierarchy of the importance of the particular ends of different individuals as because we lack the knowledge of particular facts, that the order of the Great Society must be brought about by the observance of abstract and end-independent rules." Due to the inherent limits of knowledge and reason it is simply not possible to rationally construct the whole of society, von Hayek continues to say: "But an order of the complexity of modern society can be designed neither as a whole, nor by shaping each part separately without regard to the rest, but only by consistently adhering to certain principles throughout a process of evolution" (Hayek 1973: p. 60).
} 
individual action is their generalization and universal applicability ${ }^{11}$ (cp. Kant's test of unversalizability, the Categorical Imperative: i.e. principle of treating all under the same rules). Moreover, they are end-independent and purpose-free, that means that they serve unknown particular ends. Therefore, they are mainly responsible - together with the constitutional state - for forming and preserving a spontaneous order or in Böhm's terminology: a private law society.

"What rules of just conduct in fact do is to say under what conditions this or that action will be within the range of the permissible; but they leave it to the individuals under these rules to create their own protected domain. [...] Since the consequences of applying rules of just conduct will always depend on factual circumstances which are not determined by these rules, we cannot measure the justice of the application of a rule by the result it will produce in a particular case" (pp. 37). Negative rules of just conduct are primarily prohibitions of unjust behaviour; in addition: it is only feasible to judge actions by rules, not by particular results. Particular results of a socio-economic process - which follow from the application of rules to an individual case - cannot be regarded as just or unjust (p. 32). So, negative rules do not impose any duties or obligations on anyone. Von Hayek notes: "Justice is not concerned with those unintended consequences of a spontaneous order which have not been deliberately brought about by anybody. The rules of just conduct thus merely serve to prevent conflict and to facilitate co-operation by eliminating some sources of uncertainty" (p. 38).

Von Hayek's problem with social justice is that it rolls back the transition from a small-faceto-face-society towards an abstract and spontaneous order of the Great Society. It will inevitably lead into a path towards an end-connected tribal society (teleocracy) and gradually destroy the rule-connected open society (nomocracy) (p. 38). In this regard von Hayek speaks of distributive justice as an 'atavism' and as Rousseauian nostalgia: “They are an atavism, a vain attempt to impose upon the Open Society the morals of the tribal society which, if it prevails, must not only destroy the Great Society ..." (p. 147). He continues to say: "Our present moral views undoubtedly still contain layers or strata deriving from earlier phases of the evolution of human societies - the small horde to the organized tribe, the still larger groups of clans and the other successive steps towards the Great Society" (p. 42). The (alleged) revival of 'tribal ethics' with its persistent conflict between tribal morals and commutative justice of the Great Society, with its clash between the sense of loyalty and the sense of negative justice (p. 147), and with its all-pervading loyalty to particular groups and

\footnotetext{
${ }^{11}$ According to von Hayek (1976: p. 143) "universal justice [has to be] equally applicable to the stranger and to the member of the group."
} 
communities is the greatest obstacle to a universal application of rules of just conduct. Such a revival of ancestral sentiments and organizational thinking is according to von Hayek highly related to the ideologies of socialism and nationalism. They are the main driving forces behind the prevalent constructivist rationalism and the decline in the understanding of the operation of markets (p. 134). Social justice with its anthropomorphism and personification of justice and society (Hayek 1973: pp. 26; 1976: p. 75) "serves [at least from a Hayekian perspective] to support deep-seated emotions that are threatening to destroy the Great Society" (p. 133; i.e. threat of the totalitarian state). ${ }^{12}$

As said by von Hayek, a gradual transformation from commutative to distributive justice is currently taking place. This self-accelerating ${ }^{13}$ process threatens most values of a free society, since distributive justice is wholly incompatible with the rule of law and with freedom under the law. In the end, it will directly lead to socialism and despotism subordinating citizens to authority and placing the duty of justice on authorities with power to command and coerce people (i.e. totalitarian trend). In the words of von Hayek: Social justice serves as "the Trojan Horse through which totalitarianism has entered" (p. 136).

The appeal to social justice and the demand of a just distribution of wealth leads to government action and intervention on behalf of special interest groups (p. 65). These particular rent seeking groups "... have learnt to employ the open sesame of "social justice"” (p. 67) and succeeded in "clothing their demands with the aura of legitimacy [...] by representing them as a requirement of "social justice"” (p. 141). In consequence, the call to society/public authorities in the name of social justice and the misusage of the term distributive justice has opened the floodgates "to the demand by all who found their relative position threatened that their position be protected by government action" (p. 140). Moreover, it promotes the belief that long established positions create a just expectation that they will persist and it reinforces the idea that we morally deserve what we have earned in earlier periods (pp. 93): hence, social justice leads to the protection of habitual and familiarized positions and entrenched vested interests - often camouflaged as an appeal to social justice and often disregarding the common interest of society (see e.g. p. 96). In addition, it leads to a struggle of power of organized interests in which arguments of social justice serve merely as pretexts and pretences for claims for privileges. Thus, they will destruct the Great Society with its freedom of discrimination from within (i.e. fragility of the liberal open society).

\footnotetext{
${ }^{12}$ Cp. Hayek 1976: p. 136.

${ }^{13}$ Cp. Hayek 1976: p. 68.
} 
Coming back once again to the already discussed implications of market mechanisms it is plausible from a Hayekian perspective that the concept of justice is not applicable to the results of a spontaneous order: the outcomes of market processes are simply not unjust, because: "Those shares are the outcome of a process the effect of which on particular people was neither intended nor foreseen by anyone when the institutions first appeared ..." (p. 64). "There is no need morally to justify specific distributions (of income or wealth) which have not been brought about deliberately but are the outcome of a game that is played because it improves the chances of all. In such a game nobody 'treats' people differently and it is entirely consistent with respecting all people equally that the outcome of the game for different people is very different" (p. 117). In a free and pluralistic society which lacks a common hierarchy of ends, the market order does not serve a single order or hierarchy of ends; its activities are not directed by a unique scale of ends (pp. 107). The market order, or as von Hayek describes it, the game of catallaxy $^{14}$ is a wealth-creating and poverty-eliminating game. It is a challenging competition played by individuals according to rules and decided by superior skill, talent, strengths and fortune. Von Hayek notes: "A catallaxy is thus the special kind of spontaneous order produced by the market through people acting within the rules of the law of property, tort and contract" (p. 109). "Even in a game with equal chances for all players there will be some winners and some losers" (p. 126). "In such a game in which the results for the individuals depend partly on chance and partly on their skill, there is evidently no sense in calling the outcome either just or unjust" (p. 126). Justice is simply the wrong category of evaluating market processes. As stated by von Hayek, only the conduct of the players and the rules of the game but not the results of the economic contest can be just or unjust (see p. 70). The market order is a game partly of skill and partly of chance with unpredictable outcomes (determined by skill and luck) and with winners and losers at the same time. What justice requires are the fairness of the game and the exclusion of cheating, fraud, oppression, coercion and monopoly powers. ${ }^{15}$ "The remunerations which the individuals and groups receive in the market are thus determined by what these services are worth to those who receive them... [and they are totally unrelated with needs and merits]" (p. 76). “... all that counts is the (marginal) value the services have to those to whom they are rendered. [...] based on the values the services have to the user and not on an assessment of merit earned." (p. 92). Von Hayek is convinced that all “... the attempts to 'correct' the

\footnotetext{
${ }^{14}$ I.e. discovery procedure which the competitive market order constitutes: "It is by this conveying of information in coded form that the competitive efforts of the market game secure the utilization of widely dispersed knowledge" (Hayek 1973: p. 117). And von Hayek continues to say: “... price mechanism operates as a medium of communicating knowledge" (p. 125).

${ }^{15}$ Cp. Hayek 1976: pp.73.
} 
results of the market in the direction of 'social justice' have probably produced more injustice in the form of new privileges, obstacles to mobility and frustration of efforts that they have contributed to the alleviation of the lot of the poor" (pp. 139). Thus, it is essential - at least from a Hayekian perspective - to abide by the market result also when it turns against us.

In short: Von Hayek denotes distributive or social justice as an "atavism" (Hayek 1976/1996a), as an "illusion" (Hayek 1976/1996b; 1978/1996a: p. 63) and as a "weasel-word" (Hayek 1979/1996: p. 277) - mainly used by constructivists. ${ }^{17}$ As a consequence, he pleads for a 'market economy without any attributes'. According to von Hayek, social justice is often introduced as a way to legitimize special interests and exclusive privileges, and to grant permissions and exceptions (cp. Hayek 1973/1996: pp. 252; 1976/1996a: pp. 181). Due to its vulnerability to the misuse of rent seeking groups, social justice is irreconcilable with a market economy in the terms of von Hayek (cp. Hayek 1973/1996: p. 258): i.e. the market as a self-regulating, spontaneous order $^{18}$ (kosmos) (e.g. Hayek 1966/1996: 263) and as a product of cultural evolution (see Hayek 1973: pp. 8 and 1983/1996) relying on abstract, impersonal and negative general rules or prohibitions independent of particular purposes ${ }^{19}$ and on the notion of negative freedom (cp. Hayek 1978/1996b: p. 230; 1979: pp. 130).

Let us summarise von Hayek's main reasons for dismissing the concept of social justice (cp. Hayek 1976/1996b: pp. 197): First of all, social justice (and its constructivist organization) reduces productivity, economic efficiency and, therefore, the overall wealth of a society - by not drawing on competition as a discovery procedure (Hayek 1968/2002; 1979: pp. 67) and by not drawing on the decentralized individual knowledge and know-how (cp. Hayek 1976/1996a: p. 191; 1978/1996a: p. 61). ${ }^{20}$ Second, social justice and the accompanying

\footnotetext{
${ }^{16}$ Following von Hayek, social justice rests upon basic instincts, passions and traditions of small, face-to-face communities. Therefore, social justice regarded as a relic of pre-modern times prevents the transformation towards a modern, impersonal and abstract society of commerce. By relying on inherent instincts and primitive feelings, social justice concepts are exposed to misuse by prophets and constructivists (cp. Hayek 1978/1996a: p. 55).

${ }^{17}$ A similar critique is also forwarded against the ordoliberal 'Third Way' and the concept of the Social Market Economy, often denounced as a blank or magic formula (Leer- or Zauberformel). In volume 2 of Law, Legislation and Liberty, von Hayek even speaks of social/distributive justice as an empty and meaningless concept. It is said to be meaningful only within organizations and/or a centrally planned economy. Moreover, he describes it as the "new religion of our time" (Hayek 1976: p. xii), as a "quasi-religious superstition" (p. 66), as a "cult" (p. 99), and as a "pseudo-ethics" (Hayek 1979: p. 135).

${ }^{18}$ Von Hayek distinguishes two kinds of 'order': a spontaneous order and a constructivist organization (Hayek 1966/1996: pp. 263; 1970/1996; 1973: pp. 35).

${ }^{19}$ General abstract rules - together with spontaneous order and the use of decentralized information via markets and competition - are distinctive of an open society (cp. Popper 1957/2003; 1958/2003; Hayek 1976/1996a). These kinds of rules prescribe what individuals are not to do; otherwise, they are free to pursue their own personal interests.

${ }^{20}$ Only purpose-free and end-independent general rules - rather than rules based on discretionary power and outcome considerations - allow for economic freedom in the Hayekian sense and, as a consequence, foster the overall wealth of a nation; see also Hayek 1944/2007: p. 96.
} 
(authoritative) process of correcting redistribution to the benefit of certain population groups (cp. Hayek 1976/1996a: p. 189) is necessarily attached to coercion and state interventionism resulting in a threat to individual liberty (cp. Hayek 1976/1996a: p. 191; 1976/1996b: pp. 194; 1978/1996b: p. 236 ${ }^{21}$ ). Third and finally, social justice cannot be realized due to the fact that a common criterion of justice is missing. There is simply no objective criterion of distributive justice and it seems unlikely that a common consent on what justice involves will be reached (cp. Hayek 1976/1996a: p. 182; 1978/1996b: p. 236)). By unilaterally and authoritatively prescribing a definition of justice and the way to implement a program of social justice, the problem of pretence of knowledge (Hayek 1944/2007: pp. 100; 1974/1996) arises: It is not feasible for the planning authorities to take full account of the countless changing individual needs of consumers; no one can survey the socio-economic process as a whole. Concretely, nobody knows how a just income distribution has to look like, and an externally imposed scale of incomes is necessarily connected with the violation of consumer sovereignty and will lead to totalitarian mastery (cp. Hayek 1976/1996b: pp. 197). Von Hayek even claims that distributive justice leads to economic dictatorship (cp. Hayek 1976/1996b: p. 198).

However, von Hayek is not dismissing the concept of justice as a whole; rather, although he is highly critical of the concept of (re-)distributive or social justice, he defends the concept of commutative justice respectively justice of rules, procedures and institutions (cp. Hayek 1944/2007: p. 113). Even though it is not appropriate to meaningfully assess the results of the market process according to values of social or distributive justice (i.e. market outcomes are from an ethical perspective morally neutral and the market process itself is anonymous and ethically indifferent), it is indeed permissible to evaluate the market behaviour of each of the market transaction partners. Therefore, the market game - von Hayek often refers to the market game as catallaxy (i.e. exchange game) - is liable to (procedural) justice requirements. In this regard, Vanberg (2006) distinguishes three levels of potential justice considerations: 1. rules of the game (i.e. justice of order of rules/constitution of the market) ${ }^{22} ; 2$. moves of the game (i.e. justice of behaviour respectively codes of conduct of market players); 3. results of the game (i.e. justice of outcomes of market mechanisms). ${ }^{23}$ As stated by von Hayek and Vanberg, the rules of the game have to be mainly negative, abstract and universally applicable. Their task is to legally frame and regulate the market as an arena of voluntary exchange and cooperation for mutual benefits. Formal rules and institutions have to be based

\footnotetext{
${ }^{21}$ Cp. Hayek 1944/2007: p. 117.

${ }^{22}$ Von Hayek points out that a just behavioural code is vital for a peaceful society of free individuals; however, the attempt to realise social justice is mutually incompatible with such a society (Hayek 1976/1996a: p. 181).

${ }^{23}$ The English translations of neoliberal key terms are taken from Sally (1996) and Vanberg (2004).
} 
on consensual constitutional interests and they have to be mutually and voluntarily agreeable. Under the condition that the rules of the game are fair and overall acceptable and that the behaviour of each participant complies with the rules of the game, the results of the game have to be taken as they are (i.e. there is no such thing as a redistribution according to social justice criteria). ${ }^{24}$ The outcomes of an ex-ante specified course of the game have to be accepted with all their inequalities and randomness; i.e. the results of market mechanism evade entirely their evaluation according to justice criteria or in other words: it is not permissible to apply moral categories on the outcomes of market processes, von Hayek (1973/1996: pp. 258; 1976/1996b: p. 200) states. It is merely possible to agree on procedural justice; yet, there is no guarantee of overall advantages and gains once the rules of the game have been implemented. Each game involves several risks and potential losses which have to be taken into account (ex-post correction or redistribution is not permissible once an agreement of rules and procedures has been reached). What is important is that the results of the game are coming into being under fair and just conditions and that each individual pursues his or her self-interests within the legally defined framework (i.e. rule-based adherence and compliance with the legislation). In sum: justice of procedures and rules (i.e. universal applicability of consensual rules independent of special interests) - yes; justice of (equal/egalitarian ${ }^{25}$ ) results and outcomes including just wages, just prices and a just income distribution $^{26}-$ no! Von Hayek clearly favours the concept of commutative justice and he abhors distributive or social justice focusing solely on outcomes and reallocation (see Hayek 1978/1996b: pp. 235). ${ }^{27}$

\footnotetext{
${ }^{24}$ Cp. Hayek 1978/1996b: p. 237. Essential are formal equality, impartiality, fairness and the absence of discriminations of any kind. Even an income redistribution via a progressive fiscal system is not allowed due to the fact that it violates the principle of equal treatment, non-arbitrariness and equality before the law (i.e. taxation has to be conducted according to the principle of equality and not for the purpose of redistribution; $\mathrm{cp}$. Hayek 1973/1996: p. 256; 1978/1996b: p. 238). Furthermore, redistribution is tied to the emergence of the modern welfare state with its large machinery of bureaucracy and the increase of state control even in the economic sector, while at the same time personal liberty is threatened (cp. Hayek 1960). What is needed is a demarcation of the state's tasks and a clear, transparent and strict definition of the limits of responsibility and powers of public authorities. In sum, the reallocation of incomes via a progressive tax system and to the benefit of the worst-off in a society is at odds with (von Hayek's) principle of equality before the law (cp. Hayek 1978/1996b: p. 238; see also Hayek 1960: pp. 306).

${ }^{25}$ Von Hayek is highly critical of socio-economic egalitarianism and uniformist minimum wages: cp. Hayek 1976/1996b: p. 202; 1960: pp. 48; pp. 85; pp. 285. From a Hayekian perspective, egalitarianism is highly correlated with discrimination, coercion and oppression. It is, therefore, incompatible with von Hayek's definition of liberty as the absence of constraint and compulsion. In Law, Legislation and Liberty, he clearly warns against egalitarianism and material equality (Hayek 1976: pp. 80) due to the fact that it requires economic interventionism for its fulfilment: absolute equality of material positions equals the submission of great masses under the command of some elite that manages the affairs of others. Therefore, egalitarianism can only be met by a government with despotic and totalitarian powers.

${ }^{26}$ Cp. Hayek 1944/2007: p. 140.

27 Cp. Hayek 1978/1996b: p. 235.
} 
Fundamental to von Hayek's concept of commutative justice are the already mentioned abstract general rules, the freedom to enter into contracts respectively contract law, private property and a socio-economic and legal framework or an (impersonal) order of rules guaranteeing the universal applicability and the equal compliance to rules (i.e. fairness of the game) and the prevention of fraud and deception. ${ }^{28}$ In addition, they should guarantee the equal and impartial treatment and non-discrimination of persons. By doing so, commutative justice is able to increase the overall wealth of a society and, thus, the general well-being of an average individual - even the poor are much better-off in a market society fulfilling the criteria of von Hayek compared to a centrally administered economy. According to von Hayek, commutative justice has no regard for personal needs and individual merits (in the sense of Verdienst and Bedürfnis) (Hayek 1976/1996a: p. 186; 1976/1996b: p. 196; 1960: pp. 231). ${ }^{29}$ What is important is the (economic) value of a performance in the eye of a recipient (Hayek 1976/1996b: p. 196). ${ }^{30}$ Each payment correlates to the worth of a performance pointing again at the importance of the principle of equivalence. Although it is not advisable from a Hayekian perspective to correct the (distributive) outcomes of market processes or to intervene in the market mechanism itself as (process-political) distributive justice would do, there remains one way open for social reforms: changing or correcting the rules of the game or reforming the Ordnungspolitik-level as Eucken claims. ${ }^{31}$

\section{The Ordoliberal Synthesis of Commutative and Distributive Justice}

\subsubsection{Eucken's Theory of Justice}

Contrary to von Hayek, Walter Eucken's concept of justice is multidimensional, incorporating commutative and distributive justice elements as well as justice of rules, procedures, and institutions elements. ${ }^{32}$ Even though Eucken is aware of the inherent problems of distributive or social justice - namely the potential institutionalization of discretionary powers ${ }^{33}$ via opening gateways for special interest groups leading into a Hayekian 'Road to Serfdom' (i.e.

\footnotetext{
${ }^{28}$ State authorities are responsible for monitoring the adherence to the rules of the game and for taking care, that individual behaviour pursuing self-interests within the rules of the game leads to commonly desirable results.

${ }^{29}$ Cp. Hayek 1976: p. 82.

${ }^{30}$ Cp. Hayek 1976: p. 72.

${ }^{31}$ Cp. Hayek 1973: p. 51.

${ }^{32}$ See also Vogt 1999/2009; Klump/Wörsdörfer 2010 and chapter 7.3 (Introductory Remarks) in: Wörsdörfer $2011 \mathrm{a}$

33 Two arguments speak against discretionary interventions and process policy and for preferring a ruleconstrained and rule-oriented policy over an interventionist, outcome-focused economic policy: first of all, the cognitive limits of (human) knowledge mentioned by von Hayek (i.e. constructivist rationalism commits the following faults: pretence of knowledge, absent recognition of the limits of rational control, defiance of the complex interdependencies in socio-economic systems) and secondly, the fact that discretionary interventionist government policy is much more vulnerable to rent-seeking than a government constrained in its decisions by general rules (cp. the Freiburg School of Law and Economics).
} 
slippery slope argument) - he is also conscious of the social question ${ }^{34}$ and of the so called working poor as major consequences of the industrial revolution. Thus, Eucken and other Ordoliberals endeavour to overcome the societal crisis of the present and the (new) social question - which are interlinked with the problem of socio-economic power - by granting social security, a minimum subsistence level respectively basic social care and if needed guaranteed minimum wages - and so they are referring to re-distributive instruments as well (even though the focus remains on commutative justice).

It is striking that Eucken does not provide the reader with a clear-cut and distinct definition of (social) justice. He does not offer a unified concept of justice and the normative-philosophical foundations remain fairly vague (a similar accusation is - by the way - applicable to Eucken's concept of liberty). Nonetheless, Eucken's understanding of justice is integrated in his dual criteria requirement which has to be fulfilled by an ordoliberal socio-economic order: such an order has to be functioning/efficient and humane at once (the latter is often used as a synonym for Kantian freedom and (social) justice).

In general, Eucken's competitive order is a major constituent in approaching (social) justice: the formation of incomes - based on the notion of private property as an eminent precondition of liberty and the freedom to enter into contracts - is subject to the control and sanctioning mechanisms of competition and liability (Eucken 1952/2004: p. 275; pp. 279; p. 317). Moreover, the competitive order with its focus on Ordnungspolitik is responsible for dissolving market powers, for controlling monopolies, cartels, trusts and syndicates, and for preventing the abuse of discretionary powers mainly used by rent seekers (cp. Eucken's

\footnotetext{
${ }^{34}$ Eucken distinguishes three different kinds of social questions through the ages: 1. stage of injustice and inequality of distribution (Industrial Revolution until World War I), 2. stage of (mass) long-term unemployment (1920ies/1930ies), and 3. stage of overcoming insecurity stemming from unemployment, but erosion of a new form of uncertainty, injustice and insufficient supply of necessary goods resulting from socio-economic and political power concentration (since mid-1930ies). The status quo is now dominated by powerful organizations like cartels, trusts, and labour unions; the present economic policy assumes the shape of corporatism and equals a centrally planned economy. All this caused a tremendous shift of the environmental conditions of the working class which may be characterized by three distinct aspects: scant supply of goods, injustice of distribution, and insecurity. As a consequence, the current social question incorporates all the elements of the previous ones. Moreover, a new kind of people is in the making: mass people that are solely dependent on the state; their human freedom is endangered and they equal spare parts within the big societal machine (i.e. subservience of the individual to a massive and bureaucratic state machine, in which the individual becomes a means for the achievements of the ends of the ruling class). At the heart of the new social question is, therefore, personal (un-) freedom: Security and social justice cannot be achieved without individual liberty. Thus, freedom, justice and security are inseparable; they are intertwined and not opposed to each other. The best way to solve or to overcome the social question is the creation of an ordoliberal competitive order with its unique unity of social and constitutional ordering policy. Social justice may be achieved - and the social question may be overcome via market-conforming interventions of social policy together with the establishment of a functioning institutional framework protecting civil rights and ensuring a humane and dignified life by removing private and public power concentrations. Social policy in the sense of being part of ordering policy is socially legitimate when it guarantees individual freedom and when it acts as an instrument of disempowerment (cp. Eucken 1948: p. 331; 1952/2004: pp. 122/pp. 185; 2001: pp. 38/pp. 45; Becker 1965; Külp 2000; Sally 1996).
} 
constituent and regulative principles in: Eucken 1952/2004: pp. 254). Consequently, an approximately power-free socio-economic order guarantees a relatively just income distribution by taking scarcities and shortages into consideration but not market powers ${ }^{35}$ (Eucken 1952/2004: p. 316). To put it differently: Market processes which stick to ordoliberal principles are in general fair and just. Such an order does not only promote the overall wealth of a society (cp. the above chapter on von Hayek); it also adheres to the principle of performance and capability (Leistungsfähigkeitsprinzip) and what is most important, it is in accordance with justice of contracts and exchange (Vertrags- and Tauschgerechtigkeit). The freedom to enter into contracts - another important constituent principle established by Eucken - ensures the compliance of voluntarily closed transactions and businesses; commutative justice, thus, enables the fair exchange of economic goods (Eucken 1952/2004: pp. 315).

Hence, justice is in a certain way equivalent to the outcomes of market processes - provided that power structures (and especially the abuse of powers) are absent, competition on the merits (Leistungswettbewerb) is implemented within the ordoliberal framework and guaranteed by the state authorities, and market transactions are carried out voluntarily by equal transaction partners (i.e. buyers and sellers alike) in a state of private autonomy (cp. Böhm's concept of a private law society (1966/1980)). On those conditions - referring to the ordoliberal topic of power -, economic cooperation and the division of labour ensures a level of efficiency and productivity which enhances the public good.

From an ordoliberal (and Hayekian) perspective, the market is regarded as a democratic judge; market processes incorporate in a certain way democratic elements (cp. Röpke 1944/1949: p. 61; 1942: pp. 142; 1950: pp. 205; Böhm 1966/1980: pp. 119; Eucken 1950/1996: p. 340). Market results are seen as a democratic plebiscite (depending on consumer's free choices) - given that it is a voluntary and reciprocal organization of exchanges with mutual benefits and that it takes place within a socio-economic order of complete competition (vollständiger Wettbewerb) and a minimized level of power and dependencies. Provided that all these requirements are met, the Ordoliberals speak of a market democracy in which the consumer is the sovereign and the director of the economic process and in which the producers have to follow and answer the consumer's wishes and preferences (i.e. consumarchy; cp. Röpke 1942: pp. 142; 1950: pp. 205). That is the ideal portrayal of the competitive order envisioned by Ordoliberalism (in the long run).

\footnotetext{
${ }^{35}$ On the contrary, positions based on market powers are distorting the just generation of incomes and leading to an unjust distribution of incomes.
} 
So far, similarities in the Hayekian and the ordoliberal concepts of justice exist. But, many Ordoliberals go one step further in the direction of social justice; they accredit the inevitability of distributive justice elements and as a result, they deviate from the Hayekian notion of commutative justice.

The Ordoliberals are not unworldly, quixotic or utopian ${ }^{36}$, and they are fully aware of the existing problems. Eucken and others are not oblivious to possible socio-ethical deficiencies and market failures which can occur within the ordoliberal competitive order (Eucken 1952/2004: pp. 291). Thus, it is likely that deficiencies with regard to income distribution generated by market mechanisms can occur (Eucken 1952/2004: p. 318). In this instance, a (market-conforming) correction is needed in order to prevent social cases of hardship (Eucken 1952/2004: pp. 300 and p. 318). Accordingly, Eucken develops in his book Grundsätze der Wirtschaftspolitik (Principles of Economic Policy) certain regulating principles, e.g. the correction of negative external effects ${ }^{37}$, social policy (Eucken 1953: p. 24) and income policy, particularly progressive taxation according to the ability to pay principle ${ }^{38}$ as one instrument for state-controlled redistribution (Dietze/Eucken/Lampe 1941/1942: p. 89). The aim is to secure a minimum standard of living - in special cases even minimum wages ${ }^{39}$ are appropriate (Eucken 1952/2004: pp. 303) and in general, exploitative wages are prohibited (Dietze/Eucken/Lampe 1943/2008: p. 110). Additionally, Eucken strives to implement a humane labour market which is characterized by a far-reaching balance between employees and employers, ethically tolerable working conditions and an elimination of re-feudalization. Notably, Eucken admits that labour is not a commodity (Eucken 1952/2004: p. 322)! Eucken writes: "What matters is that the labour market is organized in a humane fashion. In this regard, the following aspects have to be considered: the workman does not sell himself as a person, he does sell his services. In order to avoid exploitation, re-feudalization (Vermachtung) has to be counteracted. The relationship between [labour market] partners should be balanced. Provision for security and retributive justice is not left to the goodwill of individuals or left to chance, in a manner of speaking; rather it is subject to Ordnungspolitik"

\footnotetext{
${ }^{36}$ This does not imply that von Hayek may be accused of being so.

${ }^{37}$ The correction of negative external effects can also be seen as a part of inter-generational justice due to the fact that it incorporates environmental protection and that it strives for a sustainable economic development. The correction of external effects is discussed in ecological terms and highly related to a lasting ecological policy (see Eucken 1952/2004: pp. 301; cp. also Müller-Armack, name-giver and one of the most prominent representatives of German social market economy, 1959/1976: p. 265; 1960/1981: pp. 71; Erhard/MüllerArmack 1972: pp. 298).

${ }^{38}$ Cp. on the contrary Hayek 1960: pp. 306, where von Hayek pleads for a proportionate instead of a progressive taxation system.

${ }^{39}$ Minimum wage regulation or wage floors are closely linked to the concept of 'living wages' and wages which ensure a socially determined, sustainable and dignified living standard for workmen and their families.
} 
(Eucken 1952/2004: p. 322; translated by the author). Hecker (2008: pp. 213) observes correctly that Eucken integrates basic elements of social justice into his principles of economic policy and that a fundamental openness exists within Eucken's competitive order in terms of market-conform socio-political corrections and redistributions - naturally within certain boundaries (cp. Eucken 1952/2004: p. 301). ${ }^{40}$

Reallocation can only occur in respect of those goods which have been produced at an earlier stage; so, redistribution has to leave enough leeway for private initiatives and economic freedom including freedom of choice and decision (depending on motivation, commitment and performance incentives set by the institutional framework). Eucken is convinced that the ordoliberal competitive order fulfils this criterion of functionality and efficiency; moreover, it satisfies the criterion of humanity as well: by increasing the overall wealth of a society via an adequate economic policy and constitutional design, the amount of distributional goods and services increases likewise. What is essential here, is to broaden and widen the general participation or sharing in the raising prosperity.

In other words, commutative justice necessarily requires its completion in the form of distributive justice - at least from an ordoliberal point of view. The need for help and unindebted states of emergency call for a conception of justice which goes beyond (procedural) justice of exchange and contracts based on equality of exchange and the principle of equivalence (i.e. equal give and take, reciprocity, cooperation among equals). Equally important is the principle of subsidiarity gained from Catholic social ethics: According to that, the main emphasis lies on self-responsibility, self-help and communal or club-like help and solidarity (Eucken 1952/2004: pp. 312; Röpke 1942: p. 259; 1944/1949: p. 179; 1958/1961: pp. 249; Rüstow 1955: pp. 54). Inconsistent with the principle of subsidiarity are paternalism and a mentality of patronizing public welfare and care. In consequence, most of the Ordoliberals are highlighting individual responsibility and the importance of (state-run) security systems while criticizing the evolution of the modern (interventionist) welfare state (cp. Eucken 1952/2004: p. 319; Röpke 1933/1965: p. 175; 1942: p. 261 and p. 271; 1944/1949: pp. 171 and pp. 255; 1958/1961: p. 75, pp. 226 and p. 244; Rüstow 1957: pp. 171 and pp. 178). The redistribution has to act up to certain principles: first of all many Ordoliberals draw a distinct boundary of reallocation; they set a limit of redistribution of

\footnotetext{
${ }^{40}$ Cp. also Nutzinger/Hecker 2008: pp. 557 and Hecker 2011 (here, Hecker distinguishes between the notions of Leistungs- (justice of performance), Chancen- (justice of the starting conditions) and Bedarfsgerechtigkeit (justice of needs). While Leistungsgerechtigkeit is mainly achieved by the market, Chancen- and Bedarfsgerechtigkeit require regulatory interventions by the state. Moreover, Hecker points at the preconditions of the notion of Leistungsgerechtigkeit (i.e., freely accessible and competitive markets, consumer sovereignty, absence of power asymmetries, etc.)).
} 
income and wealth when economic investment activities are negatively affected; secondly, social policy as the bearer of redistribution should not be carried out in an isolated, selective and ad hoc manner (i.e. constitutional Ordnungspolitik instead of Punktualismus and Prozesspolitik), thirdly, it has to meet the standard of market-conformity (i.e. marketconforming redistribution), fourthly, re-distributive social and income policy should avoid centralistic and interventionist tendencies of the modern welfare state, and lastly, the execution of social policy should be free of discrimination and the granting of privileges. ${ }^{41}$

\subsubsection{Wilhelm Röpke and Alexander Rüstow: Justice of the Starting Conditions}

Alexander Rüstow and Wilhelm Röpke are rounding up the ordoliberal theories(!) of justice. It is, therefore, appropriate to say a few words about so called 'extended Ordoliberalism' or Sociological Neoliberalism: At the heart of Rüstow's and Röpke's understanding of justice lies so called justice of the starting conditions. In his book Gesellschaftskrisis der Gegenwart, Röpke speaks up for equal starting conditions and equal opportunities. ${ }^{42}$ In this context, he pleads for highly progressive inheritance taxes. Additionally, social justice consists of a broad distribution and diffusion of private property, a fight against the concentration of property in the hands of a few people or companies and a fight against diverging income disparities (Röpke 1942: pp. 356; 1958/1961: p. 348). However, Röpke does not rely solely on fair and just starting conditions; rather, he is also an advocate of justice of performance (Leistungsgerechtigkeit) (Röpke 1944/1949: p. 74): the principle of equivalence between performance and counter-performance (guaranteed by the ordoliberal competitive order) is essential as well as a meritocratic societal hierarchy (according to individual performances). In this regard, Röpke opposes (material) egalitarianism (Röpke 1950: pp. 65) and social levelling - although he does not totally condemn socio-political redistribution. He admits that these measurements underlie the principle of market-conformity.

Likewise, the ordoliberal concepts of justice are highly related - once again - with the topic of societal crisis of the present (Gesellschaftskrisis), a state of massification, disintegration and proletarianization. In complete accordance with Eucken and Rüstow, Röpke demands (limited) redistribution which removes excessive inequalities. Extreme fortune and income disparities exceeding a certain line endanger social cohesion and societal stability (cp. Böhm 1937: p. 114). Social inequalities are one major source of social upheavals. Social conflicts hinge on the economic (in-)equality between social classes. Hence, in order to avoid self-

\footnotetext{
${ }^{41}$ Cp. Gröner 1992: pp. 86; Vanberg 2008a und b.

${ }^{42}$ For a slightly different position cp. Röpke 1958/1988: pp. 257, p. 260 and p. 269.
} 
destructive socio-economic imbalances, Röpke pleads for a distributive policy (Distributionspolitik) in the form of a (more) equal (yet not egalitarian) division of property and income distribution (cp. Röpke 1942: p. 299). The best way to reach this ordoliberal goal is to promote the accumulation of assets and capital of the lower and middle classes (in combination with justice of the starting conditions). As a result, that kind of social policy will lead to de-proletarianisation and de-massification and it will contribute to solve the social question and the societal crisis of the present. Ordoliberal social policy (a la Röpke and Rüstow) is not only distributive policy; moreover, it is a policy of de-proletarianisation (Politik der Entproletarisierung) as well. Here, the main focus lies on enabling emancipation and independency as the basic fundament for autonomous, self-reliant and mature Kantian citizens. This emancipatory social policy serves as a surrogate for a lesser compensatory social policy (see also Eucken's attempt to overcome the social question in: Eucken 1948 and 2001)!

Like Röpke, Rüstow does also emphasize the significance of equal opportunities and justice of the starting conditions (i.e. assimilation ${ }^{43}$ of the starting conditions). The societal status should solely depend on each individual's meritocratic achievements. While pointing at the weight of equal starting conditions, Rüstow explicitly negates the equality of outcomes (Rüstow 1955: p. 68). In his masterpiece, Ortsbestimmung der Gegenwart, he admits that equality at the beginning (i.e. equality of opportunity) is an indispensable qualification of justice; however, equality at the end (i.e. justice of results; end-state justice (cp. Nozick 2006: pp. 201)) is (relatively) negligible (Rüstow 1957: pp. 90). One major aspect of achieving equality of the starting conditions is via education policy ${ }^{44}$ and especially via establishing a system of scholarships (Rüstow 1945/2001: p. 149; see also Röpke 1958/1988: p. 260). ${ }^{45}$ A further public task is to radically constrain the law of inheritance. ${ }^{46}$ Both facets aspire at combining justice of the starting conditions with the meritocratic performance principle (i.e. Leistungskonkurrenz). ${ }^{47}$

\footnotetext{
${ }^{43}$ When referring to the term equality, Rüstow as well as Röpke are not propagating absolute equality or even egalitarianism; rather, what should be achieved is a relative or an assimilated state of equality. Otherwise, individual freedom would be violated by a considerable degree of coercion and dominion.

${ }^{44}$ Cp. also Röpke 1963/1965; Müller-Armack 1960/1981: p. 69; 1972/1981: p. 158.

${ }^{45}$ Cp. Rüstow 2001: pp. 83: Here, Rüstow requires equal access to education and its institutions. Exclusion on the basis of lacking financial support should be prohibited. The only pivotal criterion is the performance principle: talents and achievement potentials are the only decisive factors and not the personal social or financial background.

${ }^{46}$ The aim is to overcome plutocracy mainly based on inherited inequalities with the help of an aristocratic and feudal inheritance law: every man should ideally be the architect of his own fortune (Rüstow 2001: pp. 83).

47 A just income distribution is one in which all the differences can be ascribed to different degrees of performances of the participants.
} 
Finally, Röpke as well as Rüstow are characterizing (social) justice as a meta-economic value and as a value which is highly correlated with freedom (e.g. Rüstow 1945/2001: p. 153). Thus, justice forms a unified whole, an irenic formula, with liberty!

\section{Meta-analytical Comparison}

In total, the ordoliberal theories(!) of justice consist of several elements and try to incorporate (ex ante) commutative as well as (ex post) distributive justice ${ }^{48}$ - referring both to justice of rules as well as justice of outcomes and results. It is a rule based liberalism that emphasizes procedural justice, but at the same time it is by tendency a certain form of end-state and outcome-oriented liberalism as well. It combines commutative justice elements (i.e. Tausch-, Vertrags- and Leistungsgerechtigkeit) with distributive justice elements (Verteilungsgerechtigkeit). Karsten (1985: p. 174) seems to be right when he states, that Eucken and other Ordoliberals take a middle position between Nozick's, von Hayek's and Rawls' theories of justice. ${ }^{49}$ This eclectic and syncretistic mixture of elements stemming from dissimilar theoretical backgrounds departs from the pure Hayekian notion of commutative (economic) justice. One reason for this eclecticism might be that the Ordoliberals aspire to implement an order which is economically and ethically justifiable. Thus, they provide the reader with an integrated approach combining the advantages of competition with concerns for social justice and equity. We can detect the ideal market mechanism with its minimization of economic and political power and with its fairly materialized market price as the result of complete competition. The price mechanism functions as a calculating machine and it operates as an effective communication channel linking producers' and consumers' needs in a complex and anonymous economy. Furthermore, we can detect the performance-related payment of each factor of production and an income distribution corresponding to each individual market performance, yet not depending on market power structures. Such a competitive order with its unique incentive patterns will ideally enhance the rapid and speedy enforcement and spreading of innovations and it will lead to an increase in productivity promoting the overall wealth of a society (i.e. productivity of freedom). The lower and middle classes will especially benefit from this positive amendment of social welfare. Hence,

\footnotetext{
${ }^{48}$ The terms 'ex ante' and 'ex post' refer to the different concepts of justice - justice of rules and procedures (i.e., ex ante determination of rules and procedures) respectively justice of outcomes and results (i.e., ex post correction of results).

${ }^{49}$ Accordingly, Eucken's concept represents not only a synthesis of negative and positive freedom; additionally, it represents a synthesis of Rawls' and Nozick's theories of justice as well. As Rawls, Eucken's primary concern of justice is the basic socioeconomic structure, the question of how to assign fundamental rights, duties, social conditions and institutions, and the care for the worst-off in a society (cp. In der Stunde Null 1979).
} 
competitive markets are essentially socially advantageous (cp. Böhm 1933/1964: p. 234: i.e. social productivity of self-interest).

Most of the Ordoliberals are quite aware that the primary distribution of income via concurrence and market mechanisms is economically efficient and from a commutativejustice perspective just. But, they are also conscious that the results of fair and (commutatively) just market processes are not necessarily and per se just from a distributivejustice perspective. These outcomes are not compatible with the Kantian principle of universalization and generalization. The income distribution of the markets is at first sight socially blind. In consequence, a correction or redirecting of the income distribution is required - so many Ordoliberals claim. ${ }^{50}$ It is necessary to complement the market-steered justice of performance (Leistungsgerechtigkeit) with other norms of justice. Especially the ordoliberal concern for the worst-off (cp. In der Stunde Null 1979) ${ }^{51}$ and the obligatory overcoming of absolute material poverty demands an ex-post facto correction of income distribution. As a result, many Ordoliberals not only command progressive taxation, they also command a minimum configuration of vital resources and the safeguarding of the minimum subsistence level. In other words, the society has to provide basic protection and shelter for the 'losers' of the market game respectively for those individuals and their efforts which are not appreciated and rewarded by market processes (i.e. necessities of life or in German: Bedarfs- or Bedürfnisgerechtigkeit (justice of needs)). This includes security against severe physical privation and certainty of a given minimum of sustenance for all and preclude security of a given standard of life or of the relative position. In this context, Röpke establishes his concept of economic adjustment or adaption interventions (Anpassungsinterventionen; cp. Röpke 1944/1949: p. 376). The goal of such marketconforming interventions is to 'protect' in a certain sense the workers from the vicissitudes of market forces and to grant relief and solidary help to the victims of institutional change with its multi-variant processes of adjustment - without violating the market's ability to adapt. This kind of redistribution aims at enabling a dignified life. So, questions of redistribution and issues of social or distributive justice are indeed taken into consideration. Nevertheless, the main focus is on commutative justice and the limits of redistribution are highlighted by Eucken, Röpke and Rüstow - especially with regard to the modern welfare state. The best social policy from an ordoliberal perspective is the introduction or maintenance of the competitive order complemented by anti-poverty measures and basic (mandatory) social

\footnotetext{
${ }^{50}$ See also Müller-Armack 1955: S. 85.

${ }^{51}$ I.e. market economy with a conscience: in order to protect the economically weak and to safeguard freedom, unrestrained capitalism must give way to responsible and limited market-conforming economic interventions.
} 
insurance systems. In addition, the distributive-justice concept of Ordoliberalism is quite rudimentary, elementary and in a certain way vague and indeterminate - a revision in the sense of modification and actualization is applicable and could incorporate for example societal rights of participation and inclusion as instruments for citizenship (i.e. integrating the vulnerable into a society of human dignity; in German: Mitwirkungs- or Teilhaberechte)). ${ }^{52}$

The fundamental difference to the Hayekian concept of justice is the ordoliberal incorporation of distributive-justice elements - although they are not in the centre of the ordoliberal theories - and the not at all neglected outcome-oriented perspective on social policy. ${ }^{53}$ This perspective, however, does not include equal, in the sense of egalitarian, results. Von Hayek, on the other side, completely rejects social and distributive justice as well as outcomeoriented state interventions. His focus is on formal rules and commutative justice as characteristics of a rule of law government instead of an arbitrary government (Hayek 1944/2007: p. 113; see also von Hayek's model constitution in: Hayek 1979). As stated above, von Hayek is convinced that a free economy can simply obtain commutative justice, while distributive justice is characteristic of organizations and socialism. It is the kind of justice prevalent in military and bureaucratic organizations and in a command-society, particularly in a totalitarian system of un-freedom, slavery and personal despotism (Hayek 1962/2008: pp. 642). Remarkable is the fact that the just mentioned Hayek-quotes are borrowed from von Hayek's inaugural lecture at the University of Freiburg in which von Hayek stresses the parallels in thinking of his own account and the ordoliberal one. Von Hayek is here - when he refers to social justice - either indirectly and implicitly criticizing Eucken et al. or he is simply not aware of the underlying subtle differences between Ordoliberalism and the position held by him.

Here, it is necessary to add two (preliminary) comments for the avoidance of doubt and in order to evade misunderstandings: first of all, the essay clearly pursues a (descriptive-) comparative goal elaborating the points of fine differences inside neoliberalism. With this contrasting purpose in mind, it seems legitimate to emphasize and highlight the gaps and to

\footnotetext{
${ }^{52}$ Cp. Ulrich 2008 and Goldschmidt 2011.

${ }^{53}$ A further examination question could be to investigate whether this slightly outcome-oriented perspective of Ordoliberalism is compatible with Amartya Sen's approach (cp. Sen's recently published book on justice (Sen 2009) and Goldschmidt/Lenger 2011). Sen's own approach to justice is a comparative and relational one. It is realization-focused respectively based on comparisons and comparative assessments and it focuses on the advancement or retreat of justice. The main question underlying his theory is: What (international) reforms do we need to make the world a bit less unjust? According to Sen, actual assessments of freedoms and capabilities as well as assessments of outcomes and realizations are required as a major pre-condition to make a choice between alternative policies. Sen sets his own approach apart from a contractual or arrangement focus approach to justice which aims at identifying perfectly just institutional arrangements for a society and which is based on transcendental justice.
} 
stress the points of refined distinction as a rhetorical device. However, this does not mean, that the positions held by von Hayek, Eucken, Rüstow and Röpke are mutually incompatible. To state it clearly: A sharp contrast and a diametrical opposite cannot be proved. To the contrary, a wide range of parallels do exist - particularly between (the late) Franz Böhm, a further member of the Freiburg School, Eucken and von Hayek. ${ }^{54}$ Moreover, both strands of neoliberalism can be regarded as predecessors (and representatives) of modern Constitutional Economics and they gave fresh impetus to New Institutional Economics (cp. the works of Vanberg 2008a; 2008b and Wohlgemuth 2008). Nevertheless, the differences do not have to be obliterated; the distinctions, even those which are delicate and gradual, have to be recognized. ${ }^{55}$ Secondly, there is no unified ordoliberal theory of justice or a homogenous and unitary understanding of justice; rather, (more or less) individual answers to the social question and to social justice exist, no doubt. Moreover, a complete accordance between Eucken, Rüstow and Röpke is far from certain. ${ }^{56}$ But, and that is essential, both Eucken and Rüstow/Röpke are integrating re-distributive elements into their theories of justice. Here, a common ground and a similarity between Eucken, Rüstow and Röpke can be reached. At the same time, this is also the point of departure and demarcation comparing Eucken, Rüstow and Röpke on the one hand and von Hayek on the other: The best social policy, according to the members of the Freiburg School of Law and Economics, is the introduction and preservation of the competitive order. They are favouring the integration of the question of social justice into their concept of Ordnungspolitik. The social question is regarded as a result of insufficient competition, as a result of a state of re-feudalization (Vermachtung) and as a failure of the state to implement and maintain the institutional framework. Social question, social justice and the question of private power in a free society are, therefore, interlinked (so far, the approaches of Ordoliberalism and von Hayek are more or less equivalent). In addition,

\footnotetext{
${ }^{54}$ Especially Böhm's concept of private law society closely resembles von Hayek's Great Society. See for more information on the personal relationship (not friendship!) between von Hayek and Eucken their correspondence (Hayek 1939-1950). Remarkable is the stepwise personal alienation between von Hayek and so called Economic Humanism à la Rüstow and Röpke: While von Hayek, Rüstow and Röpke were friends at an earlier age; they gradually became opponents and even enemies in their second half of life. Rüstow even called von Hayek a libertarian paleo-liberal (see Hennecke 2008: p. 149; Karabelas 2010: pp. 88; compare also the debates of the Mont Pelerin Society in Plickert 2008). As a result, the variations between von Hayek and Rüstow/Röpke are more severe compared to those between von Hayek and Böhm/Eucken. In this case, I favour the so called thesis of gradualism ranging from von Hayek's evolutionary liberalism via Ordoliberalism of the Freiburg School (Böhm and Eucken) to Sociological Neoliberalism/Economic Humanism (Röpke and Rüstow).

${ }^{55}$ Just as von Hayek is not a member of the Chicago School, he is not a member of Ordoliberalism and the Freiburg School of Law and Economics.

${ }^{56}$ Differences between Rüstow, Röpke and Eucken refer to the topic of equality of opportunity/justice of the starting conditions and education policy. Both are completely lacking in Eucken's writings. All have in common the integration of re-distributive elements (i.e. distributive justice elements are already laid down by Eucken, however, these elements play a more prominent role within the theories of justice developed by Rüstow and Röpke), the topic of Gesellschaftskrisis and the aim of overcoming the problem of socio-economic power.
} 
Ordoliberalism (in the broader sense) incorporates a (slightly) outcome-oriented perspective on social policy. Eucken's regulatory principle of income policy, for example, aims at correcting the results of market processes (i.e. income (re-) distribution via progressive taxation): Urgent (basic) needs and a minimum subsistence level have to be guaranteed via a state-run and re-distributive social policy. Moreover, Eucken does not condemn worker participation, trade unions and state-run welfare institutions complementary to private insurance companies. In special circumstances, even minimum wages are allowed (cp. Eucken's regulative principles incorporating e.g. the internalization of external effects, a redistributive income policy (i.e. progressive taxation) in order to correct socially unacceptable market outcomes, and the setting of minimum wages).

Von Hayek, on the contrary, rejects any outcome-oriented state interventions and he logically rejects (the ordoliberal) synthesis of commutative and distributive justice. Von Hayek is highly critical of redistribution via progressive taxation and he abhors minimum wages: according to him, a minimum subsistence level has to be guaranteed (i.e. securing one's livelihood), however without intervening in market processes and without (ex post) correcting market results. He clearly differentiates between securing one's livelihood, a minimum subsistence level and protection against severe deprivation (i.e. minimum income) on the one hand and minimum wage regulations or wage floors on the other (cp. e.g. Hayek 1960: pp. 285; 1960/1988: pp. 406; 1976: p. $87^{57}$ ). Insofar, von Hayek's argument is by far more consistent and stringent - compared with the ordoliberal ones. His theory of justice rests clearly on commutative justice while excluding all forms of distributive justice. The ordoliberal mixture of distributive and commutative justice-elements, to the contrary, (slightly) opens the gateway for special interest groups and it provides the state with discretionary leeway for economic policy interventions.

It is now possible to sum up the parallels and differences in the theories of justice: both Ordoliberalism and von Hayek are emphasizing Ordnungs- instead of Prozesspolitik, both are relying on competition on the merits, the principle of market conformity and the (Kantian) private law society with its freedom of privileges and discrimination; more importantly, both are warning against the dangers of the welfare state (cp. e.g. Röpke 1958/1988; Hayek 1960/1988) and the dangers of socialism and totalitarianism. Moreover, both prefer the principle of subsidiarity, self-responsibility, self-help and communal or club-like help and solidarity instead of (forced) national assistance and state-run welfare organizations. All these

\footnotetext{
${ }^{57}$ In the third volume of Law, Legislation and Liberty (Hayek 1979: pp. 93 and pp. 141), von Hayek opposes any politically determined wage structure and state-run income policies (i.e. minimum wages, etc.); instead, he favours the "assurance of a certain flat minimum income" (i.e. minimum subsistence level; p. 143).
} 
commonalities are due to the fact that both Ordoliberalism and von Hayek are - at least in their early years - fighting all kinds of totalitarian ideologies. They are all sharing similar values, pursuing similar goals and fighting on similar frontline positions. However, the applied means and the adopted specific route towards the (shared) goals are slightly different. Among the differences are: 1. Von Hayek's problem of knowledge vs. the ordoliberal problem of power: Von Hayek regards markets as processes of coordinating decentralized, widely dispersed and incomplete knowledge responsible for the allocation of factors of productivity. He supposes a division of labour as well as a division of knowledge. In this regard, market mechanisms as discovery procedures are superior and gain advantage in increasing the overall wealth of a society and thus, reaching the goal of (commutative or economic) justice. ${ }^{58}$ The ordoliberal approach is dissimilar: they are approaching justice via the problem of power and the topic of Gesellschaftskrisis: According to Ordoliberalism social justice, the social question and the reduction and prevention of the misuse of socio-economic powers are highly interlinked: Re-feudalization (among others) is one major source of injustice; 2. Von Hayek's 'impossibility theorem' (it is simply not feasible to reach a unique, consensual and generalizable definition of positive (distributive) justice) vs. the ordoliberal multi-faceted concept of justice respectively commutative vs. distributive justice: Von Hayek clearly opposes the redistribution by progressive taxation and favours proportional taxation (unlike Ordoliberalism ${ }^{59}$ ); he clearly opposes the ex post correction of market results via fiscal policy and all other measures related to distributive justice (unlike some representatives of Ordoliberalism); he clearly opposes (interventionist) social policy and state-run social security systems ${ }^{60}$ (unlike some Ordoliberals), which will lead to economic dictatorship (according to von Hayek, all distributive justice measures are compulsory tools of egalitarian and socialist redistribution); he neglects the moment of Gesellschaftskrisis which is at the heart of Ordoliberalism in the broader sense (especially Rüstow and Röpke aim at the deproletarianization, de-massification and the disempowerment of interest groups; therefore, they aim at an emancipatory social policy with a broad distribution of assets and an adequate education policy); he opposes the principle of equality of opportunities and the ordoliberal concept of justice of the starting conditions (unlike Rüstow and Röpke; cp. Hennecke 2008: pp. 113 and pp. 121). ${ }^{61}$ In short: distributive justice-elements can only be found in the

\footnotetext{
${ }^{58}$ I.e. market and justice are in this regard synonymous.

${ }^{59}$ Cp. Eucken 1952/2004: pp. 300.

${ }^{60}$ What is required - according to von Hayek - is an abolition of the government monopoly of services and the privatization and decentralization of social insurances, education, etc (Hayek 1979: p. 147).

${ }^{61}$ The concept of equality of opportunity/equal starting conditions is an "illusory ideal", as stated by von Hayek (Hayek 1976: p. 10 and pp. 84), since all still remaining handicaps and disadvantages must be removed by a
} 
ordoliberal version(s) of neoliberalism; and it is the unique balancing act between commutative and distributive justice which is a characteristic feature of German Neoliberalism.

\section{Concluding Remarks}

As stated in the introduction, variations and disparities between von Hayek and Ordoliberalism can be found on diverse levels: i.e. philosophy of science, setting dissimilar priorities, social philosophy, genesis of norms, and notion of freedom. In the current paper I have analyzed another potential dimension of differences - which is by the way interlinked with the opposed conceptions of genesis of norms: the ordoliberal and the Hayekian theories of justice with its differing setting of priorities: i.e. von Hayek's commutative justice concept vs. the ordoliberal mixture of commutative and distributive justice.

The Ordoliberals believe that true social benefits of their competitive order derive inherently from the long-term stability of competitive markets by suppressing arbitrary and disorderly political and economic power, by eliminating monopolistic and oligopolistic structures and by the ceaseless functioning of individual freedom and competition (cp. Rittershausen 2007: p. 9). Contrary to von Hayek who is convinced that the weasel-word 'social' itself is an excuse to disguise a collectivist and, hence, an anti-social agenda (e.g. social justice/social market economy), many Ordoliberals take the view that market-conforming interventions as well as re-distributive 'interventions' are indispensable in order to overcome the (new) social question. ${ }^{62}$ As a consequence, they implement 'regulating principles' which are designed - on the one hand - to stabilize and sustain the competitive order and - on the other hand - to correct certain shortcomings of the market (in modern terms: market failures). To these belong the stringent control of monopoly power, the public regulation of severe supply side anomalies such as mass unemployment, the redistribution of income through a progressive tax system and last but not least the corrections of socio-economic externalities due to large discrepancies between short-term profits and personal self-interests and the long-term common or collective good. Especially the essays originated from the interdisciplinary cooperation within the Freiburg resistance circles against National-socialism contain certain re-distributive measurements and social policy advices (cp. In der Stunde Null 1979;

powerful and coercive government; equality of opportunity is (only) important in cases of appointments to public offices (i.e. talent and skill oriented) and schooling of minors (p. 84).

${ }^{62}$ For Eucken and others, social policies are only acceptable in so far as they do not disrupt or infringe upon the primacy of stable prices in a perfectly competitive marketplace and only in so far as they are not influenced by biased interest groups and "limited in scope to truly social-fabric-ripping vagaries" (Rittershausen 2007: pp. 12). Not acceptable from an ordoliberal point of view is a Müller-Armack-like anti-cyclical policy where the state engages in vaguely defined business cycle management in order to cool off credit booms. 
Dietze/Eucken/Lampe 1941/1942 and 1943/2008): The aim of a Christian based society is a functioning and humane socio-economic order. Such an order strives for fostering selfresponsibility and proactive individual initiative. It rests on small and medium sized companies and it precludes the ruling of interest and para-governmental rent seeking groups. However, equally important is the prevention of unjust distributions of income, assets and property. It is the explicit goal of social policy to provide for humane employment with equally just payment, to avoid exploitation, mass poverty and unemployment. Eucken, for example, endorses supply anomaly interventions by subsidizing minimum wages and by guaranteeing a minimum subsistence level (Eucken 1952/2004: pp. 185, pp. 303 and pp. 321). Especially important are progressive taxes. Moreover, he - in complete accordance with Constantin von Dietze and Adolf Lampe, both members of the Freiburg (resistance) Circles pleads for equal market positions with regard to the exercise of power and influence between employers and employees (cp. Eucken 1946/1999: p. 21 and 1952/2004: p. 322). Only when the status of a balance of power has been reached on labour markets and when employers and employees are able to negotiate their working conditions at an equal level and with true freedom of contract, is it possible to minimize exploitation, reduce asymmetric, patriarchal and paternalistic employer-employee relationships, decrease dependencies and the misuse of power and realize social peace within a society. Therefore, it is one key element of social policy to support labour unions until they are equally powerful as the federation of employers or to downgrade the level of power of employers until they have just as little power as labour unions. Both parties of the labour market should be equally powerful - provided that they do not dominate economic processes and that they do not exert pressure on political decision making processes. It is a remarkable fact that Ordoliberalism connects its theories of justice with its elaborations on liberty and power (cp. also Forst 2007: pp. 270).

With all these dissimilarities in mind it is possible to draw a distinction within neoliberalism (i.e. in total, neoliberalism is no monolithic block): Von Hayek's evolutionary liberalism have to be separated from German Ordoliberalism in general and the Freiburg School of Law and Economics and Sociological Neoliberalism in particular. In addition, they challenge the stimulating thesis that von Hayek can be described as an Ordoliberal (cp. Kolev 2010). Thus, the work of Ordoliberalism should not be viewed through Hayekian lenses only; it deserves an economic-ethical perspective as well!

\section{References:}

BECKER, Helmut Paul (1965): Die soziale Frage im Neoliberalismus. Analyse und Kritik; Heidelberg, F.H. Kerle Verlag.

BÖHM, Franz (1933/1964): Wettbewerb und Monopolkampf. Eine Untersuchung zur Frage 
des wirtschaftlichen Kampfrechts und zur Frage der rechtlichen Struktur der geltenden Wirtschaftsordnung; Berlin, Carl Heymanns Verlag.

- (1937): Die Ordnung der Wirtschaft als geschichtliche Aufgabe und rechtsschöpferische Leistung; Stuttgart, Verlag von W. Kohlhammer.

- (1966/1980): Privatrechtsgesellschaft und Marktwirtschaft in: Böhm: Freiheit und Ordnung in der Marktwirtschaft; Baden-Baden, Nomos; pp. 105-168.

BÖNKER, Frank/WAGENER, Hans-Jürgen (2001): Hayek and Eucken on the State and Market Economy in: Labrousse, Agnès/Weisz, Jean-Daniel (eds.): Institutional Economics in France and Germany. German Ordoliberalism versus the French Regulation School; Berlin, Springer; pp. 183-199.

DIETZE, Constantin von/EUCKEN, Walter/LAMPE, Adolf (probably 1941/1942): Volkswirtschaftsfibel/ Nationalökonomische Fibel in: Nachlass Popitz (BA NL 1262/87), Koblenz, Bundesarchiv.

- (1943/2008): Wirtschafts- und Sozialordnung in: Goldschmidt, Nils/Wohlgemuth, Michael (eds.): Grundtexte zur Freiburger Tradition der Ordnungsökonomik; Tübingen, Mohr Siebeck; pp. 99-115.

ERHARD, Ludwig/MÜLLER-ARMACK, Alfred (1972): Soziale Marktwirtschaft. Ordnung der Zukunft. Manifest '72; Frankfurt, Ullstein Verlag.

EUCKEN, Walter (1946/1999): Über die Gesamtrichtung der Wirtschaftspolitik in: Eucken: Ordnungspolitik; Münster, LIT Verlag; pp. 1-24.

- (1948): Die soziale Frage in: Ludwig Erhard Stiftung (ed.): Grundtexte zur Sozialen Marktwirtschaft. Zeugnisse aus zweihundert Jahren ordnungspolitischer Diskussion; Stuttgart, Fischer; pp. 329-339.

- (1950/1996): Deutschland vor und nach der Währungsreform in: Schneider, Jürgen/ Harbrecht, Wolfgang (eds.): Wirtschaftsordnung und Wirtschaftspolitik in Deutschland (1933-1993); Stuttgart, Franz Steiner Verlag; pp. 327-360.

- (1952/2004): Grundsätze der Wirtschaftspolitik; Tübingen, Mohr Siebeck.

- (1953): Wettbewerb, Monopol und Unternehmer; Bad Nauheim, Vita Verlag.

- (2001): Wirtschaftsmacht und Wirtschaftsordnung - Londoner Vorträge zur Wirtschaftspolitik und zwei Beiträge zur Antimonopolpolitik; Münster, LIT Verlag.

FELD, Lars P./KÖHLER, Ekkehard A. (2011): Ist die Ordnungsökonomik zukunftsfähig? in: zfwu 12/2; pp. 173-195.

FORST, Rainer (2007): Das Recht auf Rechtfertigung. Elemente einer konstruktivistischen Theorie der Gerechtigkeit; Frankfurt, Suhrkamp.

GOLDSCHMIDT, Nils (2011): Vom Glück und von Gärten. Moderne Ordnungsökonomik und die normativen Grundlagen der Gesellschaft in: Caspari, Volker/Schefold, Bertram (eds.): Wohin steuert die ökonomische Wissenschaft? Ein Methodenstreit in der Volkswirtschaftslehre; Frankfurt, Campus Verlag.

GOLDSCHMIDT, Nils/LENGER, Alexander (2011): Teilhabe und Befähigung als Schlüsselelemente einer modernen Ordnungsökonomik in: zfwu. Zeitschrift für Wirtschaftsund Unternehmensethik 12/2; pp. 295-313.

GRÖNER, Helmut (1992): Walter Eucken - Wegbereiter der Ordnungspolitik in: Walter Eucken Institut (ed.): Ordnung in Freiheit; Tübingen, Mohr Siebeck; pp., 79-88.

HAYEK, Friedrich August von (1939-1950): Nachlass F.A. von Hayek, NL Hayek, F.A. von Hayek Papers; Stanford, Hoover Institution Archives.

- (1944/2007): The Road to Serfdom; Chicago, University of Chicago Press.

- (1960): The Constitution of Liberty; London, Routledge \& Kegan Paul.

- (1960/1988): Freiheit im Wohlfahrtsstaat in: Hohmann et al. (eds.): Grundtexte zur Sozialen Marktwirtschaft Band 2: Das Soziale in der Sozialen Marktwirtschaft; Stuttgart, Gustav Fischer Verlag; pp. 387-409.

- (1962/2008): Wirtschaft, Wissenschaft und Politik in: Goldschmidt, Nils/Wohlgemuth, 
Michael (eds.): Grundtexte zur Freiburger Tradition der Ordnungsökonomik; Tübingen, Mohr Siebeck; pp. 637-651.

- (1966/1996): Eine sich selbst bildende Ordnung für die Gesellschaft in: Kerber, Wolfgang (ed.): Die Anmaßung von Wissen, Mohr Siebeck; pp. 262-266.

- (1968/2002): Competition as a Discovery Procedure in: Quarterly Journal of Austrian Economics 5/3; pp. 9-23.

- (1970/1996): Die Irrtümer des Konstruktivismus und die Grundlagen legitimer Kritik gesellschaftlicher Gebilde in: Kerber, Wolfgang (ed.): Die Anmaßung von Wissen; Tübingen, Mohr Siebeck; pp. 16-36.

- (1973): Law, Legislation and Liberty. A new statement of the liberal principles of justice and political economy Vol. 1: Rules and Order; London, Routledge \& Kegan Paul.

- (1973/1996): Die Erhaltung des liberalen Gedankengutes in: Kerber, Wolfgang (ed.): Die Anmaßung von Wissen; Tübingen, Mohr Siebeck; pp. 249-261.

- (1974/1996): Die Anmaßung von Wissen (Pretence of Knowledge) in: Kerber, Wolfgang (ed.): Die Anmaßung von Wissen; Tübingen, Mohr Siebeck; pp. 3-15.

- (1976): Law, Legislation and Liberty Volume 2. The Mirage of Social Justice; London, Routledge \& Kegan Paul.

- (1976/1996a): Der Atavismus »sozialer Gerechtigkeit« in: Kerber, Wolfgang (ed.): Die Anmaßung von Wissen; Tübingen, Mohr Siebeck; pp. 181-192.

- (1976/1996b): Die Illusion der sozialen Gerechtigkeit in: Kerber, Wolfgang (ed.): Die Anmaßung von Wissen; Tübingen, Mohr Siebeck; pp. 193-203.

- (1978/1996a): Die drei Quellen der menschlichen Werte in: Kerber, Wolfgang (ed.): Die Anmaßung von Wissen; Tübingen, Mohr Siebeck; pp. 37-75.

- (1978/1996b): Liberalismus in: Kerber, Wolfgang (ed.): Die Anmaßung von Wissen; Tübingen, Mohr Siebeck; pp. 216-248.

- (1979): Law, Legislation and Liberty Vol. 3: The Political Order of a Free People; London, Routledge \& Kegan Paul.

- (1979/1996): Wissenschaft und Sozialismus in: Kerber, Wolfgang (ed.): Die Anmaßung von Wissen; Tübingen, Mohr Siebeck; pp. 267-277.

- (1983/1996): Evolution und spontane Ordnung in: Kerber, Wolfgang (ed.): Die Anmaßung von Wissen; Tübingen, Mohr Siebeck; pp. 102-113.

HECKER, Christian (2008): Lohn- und Preisgerechtigkeit. Historische Rückblicke und aktuelle Perspektiven unter besonderer Berücksichtigung der christlichen Soziallehren; Marburg, Metropolis-Verlag.

- (2011): Soziale Marktwirtschaft und Soziale Gerechtigkeit - Mythos, Anspruch und Wirklichkeit in: zfwu. Zeitschrift für Wirtschafts- und Unternehmensethik 12/2; pp. 269-294.

HENNECKE, Hans Jörg (2008): Friedrich August von Hayek zur Einführung; Hamburg, Junius.

IN DER STUNDE NULL (1979): Die Denkschrift des Freiburger „Bonhoeffer-Kreises“: Politische Gemeinschaftsordnung. Ein Versuch zur Selbstbestimmung des christlichen Gewissens in den politischen Nöten unserer Zeit; Tübingen, Mohr Siebeck.

KARABELAS, Iris (2010): Freiheit statt Sozialismus. Rezeption und Bedeutung Friedrich August von Hayeks in der Bundesrepublik; Frankfurt, Suhrkamp.

KARSTEN, Siegfried (1985): Eucken's 'Social Market Economy' and Its Test in Post-War West Germany: The Economist as Social Philosopher Developed Ideas That Paralleled Progressive Thoughts in America in: American Journal of Economics and Sociology 44/2; pp. 169-183.

KIRCHGÄSSNER, Gebhard (1988): Wirtschaftspolitik und Politiksystem: Zur Kritik der traditionellen Ordnungstheorie aus der Sicht der Neuen Politischen Ökonomie in: Cassel, D./Ramb, B.-T./Thieme, H.J. (eds.): Ordnungspolitik; München, Vahlen; pp. 53-75. 
KLUMP, Rainer/WÖRSDÖRFER, Manuel (2010): An Ordoliberal Interpretation of Adam Smith in: ORDO 61; pp. 29-51.

KOLEV, Stefan (2008): Macht und Wissen als Determinanten: Zur Rolle des Staates in der Wirtschaftspolitik bei Walter Eucken und Friedrich August von Hayek; retrieved October 1, 2010 from: www.hwwi.de/uploads/tx_wilpubdb/HWWI_Research_Paper_5-4.pdf.

- (2010): Hayek as an Ordo-Liberal; HWWI Research Paper 5-11; retrieved October 1, 2010 from: www.hwwi.org/uploads/tx_wilpubdb/HWWI_Research_Paper_5-11.pdf.

KÜLP, Bernhard (2000): Walter Eucken und die soziale Frage in: Külp, Bernhard/Vanberg, Viktor (eds.): Freiheit und wettbewerbliche Ordnung. Gedenkband zur Erinnerung an Walter Eucken; Freiburg, Haufe Verlag; pp. 155-176.

MÜLLER-ARMACK, Alfred (1955): Wirtschaftspolitik in der sozialen Marktwirtschaft in: Boarman, Patrick (ed.): Der Christ und die soziale Marktwirtschaft; Stuttgart, W. Kohlhammer Verlag; pp. 75-99.

- (1959/1976): Die Soziale Marktwirtschaft nach einem Jahrzehnt ihrer Erprobung in: MüllerArmack: Wirtschaftsordnung und Wirtschaftspolitik. Studien und Konzepte zur Sozialen Marktwirtschaft und zur Europäischen Integration; Bern, Haupt; pp. 251-265.

- (1960/1981): Die zweite Phase der Sozialen Marktwirtschaft: Ihre Ergänzung durch das Leitbild einer neuen Gesellschaftspolitik in: Ludwig Erhard Stiftung (ed.): Grundtexte zur Sozialen Marktwirtschaft. Zeugnisse aus zweihundert Jahren ordnungspolitischer Diskussion; Stuttgart, Fischer; pp. 63-78.

- (1972/1981): Die Soziale Marktwirtschaft und ihre Widersacher in: Müller-Armack: Genealogie der Sozialen Marktwirtschaft; Bern, Haupt; pp. 147-160.

NOZICK, Robert (2006): Anarchie. Staat. Utopia; München, Olzog Verlag.

NUTZINGER, Hans G./HECKER, Christian (2008): Gerechtigkeit in der Ökonomie - ein unlösbarer Widerspruch? in: Leviathan 4/2008; pp. 543-575.

PIES, Ingo (2001): Eucken und von Hayek im Vergleich. Zur Aktualisierung der ordnungspolitischen Konzeption; Mohr Siebeck, Tübingen.

PLICKERT, Philipp (2008): Wandlungen des Neoliberalismus. Eine Studie zu Entwicklung und Ausstrahlung der „Mont Pèlerin Society“; Lucius \& Lucius, Stuttgart.

POPPER, Karl R. (1957/2003): Die offene Gesellschaft und ihre Feinde. Band I: Der Zauber Platons; Tübingen, Mohr Siebeck.

- (1958/2003): Die offene Gesellschaft und ihre Feinde. Band II: Falsche Propheten: Hegel, Marx und die Folgen; Tübingen, Mohr Siebeck.

QUAAS, Friedrun (2000): Soziale Marktwirtschaft. Wirklichkeit und Verfremdung eines Konzepts; Bern, Verlag Paul Haupt.

RENNER, Andreas (1999/2000): Die zwei „Neoliberalismen“ in: Fragen der Freiheit 256; retrieved July 11, 2010 from www.tristanabromeit.de/pdf/MdB\%20Gruene\%20Anhang\%20I.pdf.

RITTERSHAUSEN, Johannes R.B. (2007): The Postwar West German Economic Transition: From Ordoliberalism to Keynesianism; Köln, IWP Discussion Paper No. 2007/1, Institut für Wirtschaftspolitik.

RÖPKE, Wilhelm (1933/1965): Epochenwende? in: Röpke: Fronten der Freiheit. Wirtschaft Internationale Ordnung - Politik. Eine Auslese aus dem Gesamtwerk; Stuttgart, Seewald Verlag; pp. 167-178.

- (1942): Die Gesellschaftskrisis der Gegenwart; Erlenbach, Rentsch.

- (1944/1949): Civitas Humana. Grundfragen der Gesellschafts- und Wirtschaftsreform; Erlenbach, Rentsch.

- (1950): Mass und Mitte; Erlenbach, Rentsch.

- (1958/1961): Jenseits von Angebot und Nachfrage; Erlenbach, Rentsch. 
- (1958/1988): Gefahren des Wohlfahrtsstaates in: Hohmann, Karl et al. (eds.): Grundtexte zur Sozialen Marktwirtschaft. Das Soziale in der Sozialen Marktwirtschaft; Stuttgart, Gustav Fischer Verlag; pp. 253-270

- (1963/1965): Die Stellung der Wissenschaft in der Industriegesellschaft in: Röpke: Fronten der Freiheit. Wirtschaft - Internationale Ordnung - Politik. Eine Auslese aus dem Gesamtwerk; Stuttgart, Seewald Verlag; pp. 214-227.

RÜSTOW, Alexander (1945/2001): Das Versagen des Wirtschaftsliberalismus; Marburg, Metropolis.

- (1955): Wirtschaftsethische Probleme der sozialen Marktwirtschaft in: Boarman, Patrick (ed.): Der Christ und die soziale Marktwirtschaft; Stuttgart, Kohlhammer Verlag; pp. 53-74.

- (1957): Ortsbestimmung der Gegenwart. Eine universalgeschichtliche Kulturkritik. Dritter Band. Herrschaft oder Freiheit?; Erlenbach, Rentsch.

- (2001): Die Religion der Marktwirtschaft; Münster, LIT Verlag.

SALLY, Razeen (1996): Ordoliberalism and the Social Market: Classical Political Economy from Germany in: New Political Economy 1/2; pp. 1-18.

SEN, Amartya (2009): The Idea of Justice; Cambridge, Harvard University Press.

STREIT, Manfred E./WOHLGEMUTH, Michael (2000a): Walter Eucken und Friedrich A. von Hayek: Initiatoren der Ordnungsökonomik in: Külp, Bernhard/Vanberg, Viktor (eds.): Freiheit und wettbewerbliche Ordnung. Gedenkband zur Erinnerung an Walter Eucken; Freiburg, Haufe Verlag; pp. 461-498.

- (2000b): The Market Economy and the State. Hayekian and Ordoliberal Conceptions in: Koslowski, Peter (ed.): The Theory of Capitalism in the German Economic Tradition. Historism, Ordo-Liberalism, Critical Theory, Solidarism; Heidelberg, Springer; pp. 224-271.

ULRICH, Peter (2008): Integrative Economic Ethics. Foundations of a Civilized Market Economy; Cambridge, Cambridge University Press.

VANBERG, Viktor (1988): „Ordnungstheoriee as Constitutional Economics. The German Conception of a „Social Market Economy“e in: ORDO 39; pp. 17-31.

- (2004). The Freiburg School: Walter Eucken and Ordoliberalism; available at: www.eucken.de/publikationen/04_11bw.pdf.

- (2006): Marktwirtschaft und Gerechtigkeit. Zu F.A. Hayeks Kritik am Konzept der „sozialen Gerechtigkeit“ in: Held, Martin/Kubon-Gilke, Gisela/Sturn, Richard (eds.): Soziale Sicherung in Marktgesellschaften; Marburg, Metropolis Verlag; pp. 39-69.

- (2008a): Der konsensorientierte Ansatz der konstitutionellen Ökonomik in: Vanberg, Viktor: Wettbewerb und Regelordnung; Tübingen, Mohr Siebeck; pp. 23-48.

- (2008b): Die normativen Grundlagen von Ordnungspolitik in: Vanberg, Viktor: Wettbewerb und Regelordnung; Tübingen, Mohr Siebeck; pp. 49-67.

VOGT, Markus (1999/2009): Soziale Interaktion und Gerechtigkeit in: Handbuch der Wirtschaftsethik Bd. 1.1.: Verhältnisbestimmung von Wirtschaft und Ethik. Konstitutive Bauelemente moderner Wirtschaftsethik. Grundfragen ethischer Rationalität in einer globalen Welt; Berlin, Berlin University Press; pp. 284-309.

WATRIN, Christian (2000): Staatsaufgaben: Die Sicht Walter Euckens und Friedrich A. von Hayeks in: Külp, Bernhard/Vanberg, Viktor (eds.): Freiheit und wettbewerbliche Ordnung. Gedenkband zur Erinnerung an Walter Eucken; Freiburg, Haufe Verlag; pp. 323-343.

WÖRSDÖRFER, Manuel (2010): Ordoliberalism and the Evolution of Norms; Working Paper Series 07/2010, Cluster of Excellence "The Formation of Normative Orders".

- (2011a): Die normativen und wirtschaftsethischen Grundlagen des Ordoliberalismus; Frankfurt.

- (2011b): Individual and Regulatory Ethics: An Economic-Ethical and Theoretical-Historical Analysis of Ordoliberalism; Working Paper Series 07/2011, Cluster of Excellence "The Formation of Normative Orders". 
WOHLGEMUTH, Michael (2008): A European Social Model of State-Market Relations. The Ethics of Competition from a "Neo-liberal" Perspective in: zfwu 9/1; pp. 69-87. 